\title{
KEABSAHAN PENERAPAN PASAL 93 UNDANG- UNDANG KEKARANTINAAN KESEHATAN DI WILAYAH YANG TIDAK MENETAPKAN PEMBATASAN SOSIAL BERSKALA BESAR
}

\author{
I Wayan Suardana, Program Studi Magister Ilmu Hukum, Fakultas Hukum \\ Universitas Udayana, Email: info@gendolawoffice.com \\ I Gusti Ngurah Wairocana, Fakultas Hukum Universitas Udayana, \\ Email: wairocanangurah@yahoo.co.id \\ Ida Bagus Surya Dharma Jaya, Fakultas Hukum Universitas Udayana, \\ Email: surya_dharma@unud.ac.id
}

doi: https://doi.org/10.24843/KS.2020.v08.i09.p13

\begin{abstract}
Abstrak
Tujuan Penelitian Ini adalah untuk mengetahui keabsahan penerapan Pasal 93 Undang-Undang Nomor 6 Tahun 2018 tentang Kekarantinaan Kesehatan di wilayah yang belum memberlakukan penyelenggaraan kesehatan masyarakat in casu PSBB. Metode penelitian yang digunakan untuk menganalisis permasalahan diatas adalah penelitian hukum normatif, dengan pendekatan perundangundangan, pendekatan koseptual, pendekatan kasus, pendekatan fakta. Sumber bahan hukum yang digunakan adalah sumber bahan hukum primer, sumber bahan hukum sekunder dan sumber bahan hukum tersier. Teknik analisis bahan hukum yang digunakan untuk menganalisis adalah teknik deskriptif dan teknik interpretasi sistematis. Hasil Penelitian menunjukkan bahwa Pasal 93 UU KK tidak dapat diterapkan terhadap kegiatan ngaben massal Dadia Pasek Kubayan, di Desa Sudaji, Kecamatan Sawan Kabupaten Buleleng Provinsi Bali sehingga penetapan Made Suwardana (Ketua Panitia Pelaksana) sebagai Tersangka tidak sah hukum.
\end{abstract}

Kata Kunci: Keabsahan, Pasal 93 UUKK, PSBB, Sudaji

\begin{abstract}
The aim of this research is to know the validity of the application of article 93 of Law No. 6/2018 about Health Quarantine (UU KK) in areas where the implementation of public health in casu PSBB has not been enforced. The reseacrh methods used to analyze problems is normative research, with statute approach, conceptual approach, case approach, and fact approach. It consists of primary, secondary and teritary sources of legal material. The technique of collecting the legal materials are descriptive and systematic interpretative. The result of the research shows that Article 93 UU KK can not be implemented for mass ngaben activity in Sudaji Village, Sawan Sub-Distric, Buleleng Distric, Bali Province. Therefore, the determination of the suspect Mr. Made Suwardana (the chief of executive committee) is not legally valid.
\end{abstract}

Key Words: Legality, article 93 UUKK, PSBB, Sudaji

\section{Pendahuluan}

\subsection{Latar Belakang Masalah}

Pada 11 maret 2020, Organisasi Kesehatan Dunia (World Health Organization/WHO) melalui Direktur Jendralnya, Tedros Adhanom Ghebreyesus, secara resmi menetapkan wabah Corona Virus Disease 19 (Covid 19) sebagai pendemi 
global. Hal ini dinyatakan setelah Covid 19 menyebar ke 118 negara dan menginfeksi 119.179 orang. ${ }^{1}$ Dalam menghadapi situasi ini WHO mengklasifikasikan Covid 19 sebagai pandemi global. Lebih lanjut Jon Cohen, dan Kai Kupferschmidt mengatakan "As Science went to press, the World Health Organization (WHO) still avoided using the word "pandemic" to describe the burgeoning crisis, instead talking about epidemics in different parts of the world."2 (Terjemahan bebas: "Ketika ilmu pengetahuan mulai ditekan, Organisasi Kesehatan Dunia (WHO) masih menghindari penggunaan kata "pandemi" untuk menggambarkan krisis yang sedang berkembang, alih-alih berbicara tentang epidemi di berbagai belahan dunia."

Indonesia menyikapi situasi pandemi Covid 19 untuk menekan meluasnya penyebaran virus ini. 3 Penyebaran Covid 19 berpotensi menimbulkan kegawatdaruratan kesehatan, sehingga untuk mencegah meluasnya dampak virus ini diperlukan seperangkat regulasi. ${ }^{4}$ Keputusan Presiden Republik Indonesia, Ir. Joko Widodo, pada 31 maret 2020, menetapkan status darurat kesehatan masyarakat terkait wabah Covid 19 dan memilih Pembatasan Sosial Berskala Besar (PSBB) sebagai respon untuk mengatasi dampak wabah Covid 19 tersebut, sebagaimana yang diatur dalam Undang-Undang Nomor 6 Tahun 2018 tentang Kekarantinaan kesehatan (selanjutnya dalam tulisan ini disebut dengan UU KK). ${ }^{5}$ Kebijakan ini merupakan langkah sigap pemerintah dalam menanggulangi pandemi covid 19.6 Keputusan Presiden mengenai penetapan darurat Kesehatan Masyrakat tersebut dituangkan ke dalam Keputusan Presiden Nomor 11 Tahun 2020 tentang Penetapan Kedaruratan Kesehatan Masyarakat

1 https://health.grid.id/read/352059111/who-resmi-nyatakan-covid-19-sebagaipandemi-global-setelah-menyebar-ke-118-negara?page=all diakses pada 27 mei 2020 pukul 19.13 wita. Lihat juga; https://www.vivanews.com/berita/dunia/40129-virus-corona-resmijadi-pandemi-apa-artinya diakses pada 27 mei 2020 pukul 19.13 wita

2Jon Cohen and Kai Kupferschmidt, 2020 "Strategies shift as coronavirus pandemic looms", Science, Vol. 367, Issue 6481, February 2020, h. 962-963.

${ }^{3}$ Engkus, et al, 2020, "Covid-19: Kebijakan mitigasi penyebaran dan dampak sosial ekonomi di Indonesia." LP2M, Mei 2020, h. 9.

${ }^{4}$ Dalinama Telaumbanua, 2020, "Urgensi Pembentukan Aturan Terkait Pencegahan Covid-19 Di Indonesia", QALAMUNA: Jurnal Pendidikan, Sosial, dan Agama, Nomor 1, Pebruari 2020, h. 59.

5 https://news.detik.com/berita/d-4959761/pandemi-corona-jokowi-tetapkan-statusdarurat-kesehatan-masyarakat diakses pada 27 mei 2020 pada pukul 19.32 wita,

https://nasional.kompas.com/read/2020/03/31/15265391/jokowi-tetapkan-statusdarurat-kesehatan-masyarakat diakses pada 27 mei 2020 pada pukul 19.32 wita,

${ }^{6}$ Imas Novita Juaningsih, 2020, "Penerapan Sanksi Pidana bagi Penimbun Masker di Indonesia Selama Masa Pandemi Covid-19." 'ADALAH, Nomor 1, 2020, h. 76. 
Covid 197 dan selanjutnya pada 1 April 2020, pemerintah menerbitkan Peraturan Pemerintah Nomor 21 Tahun 2020 tentang Pembatasan Sosial Berskala Besar dalam rangka Percepatan Penanganan Corona Virus Disease 2019 (Covid 19)8 (selanjutnya dalam tulisan ini akan disebut PP PSBB).

Menteri Kesehatan menerbitkan Peraturan Menteri Kesehatan Nomor 9 Tahun 2020 tentang Pedoman Pembatasan Sosial Berskala Besar Dalam rangka Percepatan Penanganan Corona Virus Disease 2019 (Covid 19) ${ }^{9}$ (selanjutnya akan disebut Permenkes Pedoman PSBB) dengan adanya Keputusan Presiden tersebut maka dapat dinyatakan bahwa untuk percepatan penanggulangan wabah covid 19, Presiden telah menetapkan darurat kesehatan masyarakat covid 19 dan memilih PSBB sebagai penyelenggaraan kekarantinaan kesehatan, halmana PSBB adalah sebagai respon kedaruratan kesehatan masyarakat yang telah ditetapkan. Dengan demikian, mengingat bahwa di dalam UU KK dimaksud, guna penyelenggaran kekarantinaan masyarakat in casu PSBB, Pemerintah dapat bekerjasama dengan Pemerintah Daerah (Pemda) maka sejak penetapan tersebut Pemda dapat mengajukan penyelenggaraan PSBB di daerahnya masing-masing kepada Pemerintah c.q Menteri Kesehatan sebagaimana diatur dalam UUKK jo. PP PSBB jo. Permenkes Pedoman PSBB.

Selanjutnya, dalam UU KK mengatur mengenai sanksi pidana atas pelanggaran penyelenggaraan kekarantinaan kesehatan diatur pada Pasal 93 UU KK yang menyatakan:

“Setiap orang yang tidak mematuhi penyelenggaraan Kekarantinaan Kesehatan sebagaimana dimaksud dalam Pasal 9 ayat (1) dan/atau menghalang-halangi penyelenggaraan kekarantinaan kesehatan sehingga menyebabkan Kedaruratan Kesehatan Masyarakat dipidana dengan pidana penjara paling lama 1 (satu) tahun dan/atau pidana denda paling banyak Rp. 100.000 .000 (seratus juta rupiah).

7 https://nasional.okezone.com/read/2020/04/01/337/2192229/isi-lengkap-keppreskedaruratan-kesehatan-masyarakat-covid-19-ditetapkan-presiden-jokowi diakses pada 27 mei 2020 pada pukul 19.35 wita.

8 https:// www.cnbcindonesia.com/news/20200401130638-4-149058/terbitkan-pp-psbbjokowi-ungkap-alasan-tak-lakukan-lockdown diakses pada 27 mei 2020 pukul 19.42 wita. Lihat juga; $\quad$ https://nasional.kontan.co.id/news/hadapi-corona-pemerintah-terbitkan-pppembatasan-sosial-berskala-besar, diakses pada 27 mei 2020 pukul 19.42 wita.

${ }^{9} \mathrm{https}$ // www.antaranews.com/berita/1403506/permenkes-nomor-9-tahun-2020-aturpelaksanaan-psbb diakses pada 27 mei 2020 pukul 19.44 wita. Lihat juga; https://mediaindonesia.com/read/detail/304863-permenkes-nomor-92020-harus-jadipedoman-penerapan-psbb , pada 27 mei 2020 pukul 19.44 wita. 
Dalam Pasal 9 ayat (1) UU KK menyatakan: "Setiap orang wajib mematuhi penyelenggaraan Kekarantinaan Kesehatan"

Sejak ditetapkannya Keputusan Presiden Darurat Kesehatan Masyarakat Covid 19 dengan PSBB sebagai responnya, banyak daerah yang telah menyelenggarakan PSBB sebagaimana diatur oleh ketentuan peraturan perundang-undangan. Hingga 22 April 2020, berdasarkan pernyataan BNPB, terdapat 2 (dua) provinsi dan 21 (dua puluh satu) kabupaten/kota yang telah menyelenggarakan PSBB dan ada 7 (tujuh) daerah lainnya yang sedang dalam melengkapi persyaratannya. ${ }^{10}$ Namun demikian, hingga tulisan ini disusun, tidak ada satupun Pemda di Bali baik Provinsi maupun Kabupaten/Kota yang menyelenggarakan PSBB, Pemerintah Provinsi Bali maupun Pemerintah Kabupaten/Kota tidak ada yang menyelenggarakan PSBB. Bahkan Pemerintah Provinsi Bali telah menegaskan berulangkali bahwa mereka tidak mau menerapkan PSBB guna menanggulangi covid, 11 bahkan mengklaim sukses menanggulangi wabah Covid 19 tanpa perlu menyelenggarakan PSBB. ${ }^{12}$

Di sisi lain, terdapat beberapa peristiwa hukum di Bali yang diangkat sebagai permasalahan hukum, terkait sanksi hukum terhadap masyarakat yang melanggar imbauan Pemda. Salah satunya yang mencuat adalah adanya pelaksanaan prosesi ngaben massal Dadia Pasek Kubayan, di Desa Sudaji, Kecamatan Sawan Kabupaten Buleleng Provinsi Bali yang dilakukan pada 1 April 2020. Atas peristiwa tersebut akhirnya Kepolisian Resor Buleleng melakukan penyelidikan karena kegiatan tersebut dinilai melanggar Maklumat Kapolri dan imbauan Pemerintah, terkait social dan physical distancing. Akhirnya pada 3 Mei 2020, Ketua Panitia Pelaksana Ngaben Massal yakni; Made Suwardana ditetapkan sebagai Tersangka dan dijerat

10 https://nasional.kompas.com/read/2020/04/22/19520061/bnpb-sudah-2-provinsidan-21-kabupaten-kota-yang-terapkan-psbb, diakses pasa 27 mei 2020 , pada pukul 20.30 wita.

${ }^{11} \mathrm{https} / /$ mediaindonesia.com/read/detail/308807-bali-bersikukuh-tolak-ajukan-psbb

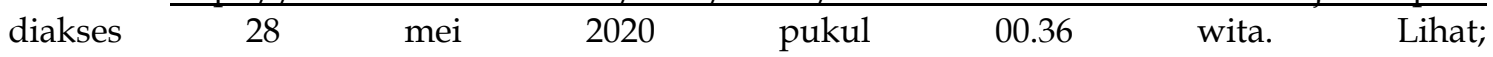
https:// www.nusabali.com/berita/72379/gubernur-koster-belum-memperhitungkanpenerapan-psbb-di-bali, diakses 28 mei 2020 pukul 00.36 wita.

12 https:// bali.tribunnews.com/2020/05/10/3-indikator-bali-lebih-efektif-kendalikanpenyebaran-covid-19-dibanding-daerah-lain-terapkan-psbb, diakses 28 Mei 2020 pukul 00.43 wita. Lihat; https://news.detik.com/berita/d-5012616/ini-strategi-bali-berhasil-lawan-coronatanpa-psbb diakses pada 28 mei 2020 , pukul 00.44 wita. Lihat; https://www.liputan6.com/regional/read/4247452/tanpa-psbb-bali-klaim-sukses-atasicorona, pada 28 mei 2020 , pukul 00.44 wita; LIhat; https:// www.tribunnews.com/corona/2020/05/10/ini-strategi-yang-dipakai-gubernur-balihingga-sukses-kendalikan-penyebaran-covid-19-tanpa-psbb , diakses 28 Mei 2020 pukul 00.44 wita 
dengan Pasal 14 ayat (1) Undang-Undang Nomor 4 Tahun 1984 tentang Wabah Penyakit Menular dengan hukuman penjara 1 tahun atau denda maksimal Rp 100 juta, dan atau Pasal 93 UU KK dengan hukuman 1 (satu) tahun penjara dan/atau pidana denda paling banyak Rp 100 juta. ${ }^{13}$

\subsection{Rumusan Masalah}

Penetapan tersangka atas peristiwa proses ngaben massal tersebut selanjutnya menimbulkan permasalahan hukum. Namun demikian untuk membatasi penulisan ini, penelitian ini membahas penerapan Pasal 93 UU KK dalam kasus ini. Dengan pertanyaan hukum sebagai berikut: 1) Bagaimanakah keabsahan Penerapan Pasal 93 UU KK terhadap Ketua Panitia Pelaksana Ngaben Massal Dadia Pasek Kubayan, di Desa Sudaji, Kecamatan Sawan Kabupaten Buleleng Provinsi Bali?

\subsection{Tujuan Penelitian}

Tujuan penelitian ini adalah untuk mengetahui keabsahan penerapan Pasal 93 UU KK di wilayah yang tidak menetapkan penyelenggaran Kekarantinaan Kesehatan in casu PSBB.

\section{Metode Penelitian}

Metode penelitian yang digunakan untuk menganalisis permasalahan di atas adalah penelitian hukum normatif. Penelitian ini mengkaji mengenai kekaburan norma yakni legalitas penerapan Pasal 93 UU KK di wilayah yang tidak menetapkan penyelenggaraan Kekarantinaan Kesehatan in casu PSBB. Pendekatan masalah dilakukan dengan pendekatan perundang-undangan (statute approach), pendekatan konseptual (conceptual approach), pendekatan kasus (case approach), pendekatan fakta (fact approach). Sumber bahan hukum yang digunakan adalah sumber bahan hukum primer, sumber bahan hukum sekunder dan sumber bahan hukum tersier. Teknik analisis bahan hukum yang digunakan untuk menganalisis adalah teknik deskriptif dan teknik interpretasi sistematis yakni dengan mengaitkan peraturan yang satu dengan yang lainnya untuk menjawab permasalahan mengenai legalitas penerapan

13 https://radarbali.jawapos.com/read/2020/05/04/192390/ketua-panitia-ngabenmassal-di-desa-sudaji-dijadikan-tersangka diakses pada 28 mei 2008, pukul 01.12 wita, Lihat; https://regional.kompas.com/read/2020/05/04/16184561/warga-berkerumun-saat-upacarangaben-ketua-panitia-jadi-tersangka?page $=$ all, diakses pada 28 mei 2008, pukul 01.12 wita, 
Pasal 93 UU KK di wilayah yang tidak menetapkan penyelenggaraan Kekarantinaan Kesehatan in casu PSBB.

\section{Hasil dan Pembahasan}

Sebagaimana yang telah diuraikan pada Bab I bagian latar belakang bahwa dalam rangka menanggulangi wabah pandemi Covid 19, pemerintah telah menerbitkan Keputusan Presiden Nomor 11 Tahun 2020 tentang Darurat Kesehatan Masyarakat Covid 19. Keputusan ini sesuai dengan amanat Pasal 10 ayat (1) s/d ayat (3) UUKK yang memberikan kewenangan kepada pemerintah pusat untuk menetapkan dan mencabut kedaruratan kesehatan masyarakat dengan terlebih menetapkan jenis penyakit dan faktor resiko yang dapat menimbulkan kedaruratan kesehatan masyarakat.

Secara normatif, dengan adanya penetapan status darurat kesehatan masyarakat ini maka Pemerintah selanjutnya dapat melakukan penetapan dan melaksanakan penyelenggaraan kekarantinaan kesehatan. Hal ini sebagaimana diatur dalam Pasal 11 ayat (1) UU KK yang menyebutkan: "penyelengggaraan kekarantinaan kesehatan pada darurat kesehatan masyarakat dilaksanakan oleh Pemerintah pusat secara cepat dan tepat berdasarkan besarnya ancaman, efektifitas, dukungan sumber daya, dan teknik operasional dengan mempertimbangkan kedaulatan negara, keamanan, ekonomi sosial dan budaya." Kewenangan ini sebagai pengejewantahan dari tanggung jawab Pemerintah pusat dan daerah dalam melindungi kesehatan masyarakat dari penyakit dan/atau faktor risiko kesehatan masyarakat yang berpotensi menimbulkan kedaruratan kesehatan masyarakat melalui penyelenggaraan kekarantinaan

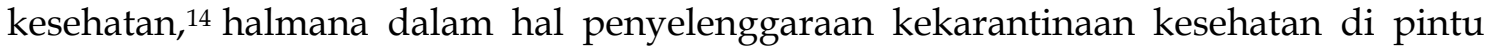
masuk dan wilayah, pemerintah menyelenggarakan secara terpadu dan dalam penyelenggaraannya pemerintah dapat melibatkan pemerintah daerah. Mengenai kekarantinaan kesehatan pintu masuk dan di wilayah dinyatakan dalam Pasal 15 ayat (1) UU KK yang menyatakan:

"Kekarantinaan kesehatan di pintu masuk dan di wilayah (garis bawah dari Penulis) dilakukan melalui kegiatan pengamatan penyakit dan faktor risiko kesehatan masyarakat terhadap alat angkut, orang, barang, dan/atau lingkungan, serta respons terhadap kedaruratan kesehatan masyarakat dalam bentuk tindakan kekarantinaan kesehatan."

14lihat pasal 4 UUKK 
Pada ayat (2) menyatakan:

Tindakan kekarantinaan kesehatan sebagaimana dimaksud pada ayat (1) berupa:

a) Karantina (garis bawah dari Penulis), isolasi, pemberian vaksinasi atau profilaksis, rujukan, disinfeksi, dan/atau dekontaminasi terhadap orang sesuai indikasi;

b) Pembatasan Sosial Berskala Besar; (garis bawah dari Penulis);

c) Disinfeksi, dekontaminasi, diinseksi, dan/atau deratisasi terhadap alat angkut dan barang; dan/atau

d) Penyehatan, pengamanan dan pengendalian terhadap media lingkungan

Selanjutnya sebagai respon atas penetapan darurat kesehatan masyarakat tersebut, Presiden menetapkan Pembatasan Sosial Berskala Besar (PSBB) sebagai respons kedaruratan kesehatan yang digunakan dalam menanggulangi dampak Covid 19 dengan menerbitkan PP PSBB. Dalam Pasal 1 PP PSBB menyatakan: “Dalam Peraturan Pemerintah ini, yang dimaksud dengan Pembatasan Sosial Berskala Besar adalah pembatasan kegiatan tertentu Penduduk dalam suatu wilayah yang diduga terinfeksi corona virus disease 2019 (Covid-2019) sedemikian rupa untuk mencegah kemungkinan penyebaran corona virus disease 2019 (Covid-2019)." Hal ini sesuai dengan Pasal 59 ayat (1) dan ayat (2) yang menyatakan:

(1) Pembatasan sosial berskala besar merupakan bagian dari respons kedaruratan kesehatan masyarakat

(2) Pembatasan sosial berskala besar bertujuan mencegah meluasnya penyebaran penyakit kedaruratan kesehatan masyarakat yang sedang terjadi antar orang di suatu wilayah;

Sebelum lebih lanjut, diuraikan apakah PP PSBB ini merupakan penyelenggaraan kekarantinaan kesehatan di wilayah sebagaimana dimaksud di Bab VIII UU KK atau tidak? Tentu pertanyaan ini dapat dijelaskan dengan memperhatikan muatan dari PP PSSB dimaksud dengan cara membandingkan penyelenggaraan kekarantinaan kesehatan di wilayah c.q PSBB dalam UU KK dengan yang dimuat dalam PP PSBB. Terdapat beberapa hal yang dapat digunakan untuk memastikan hal tersebut, diantaranya: Pasal 2 ayat (1) PP PSBB yang menyatakan:

(1) Dengan persetujuan menteri yang menyelenggarakan urusan pemerintahan di bidang kesehatan, pemerintah daerah dapat melakukan pembatasan sosial berskala besar atau pembatasan terhadap pergerakan orang dan barang untuk satu provinsi atau kabupaten / kota tertentu. 
Ketentuan ini dapat dikualifikasi sebagai amanat dari Pasal 49 ayat (3) UU KK yang menyatakan : "Karantina wilayah dan pembatasan sosial berskala besar (garis bawah dari Penulis) sebagaimana dimaksud ayat (1) ditetapkan oleh menteri (garis bawah dari Penulis).

Demikian pula pada Pasal 2 ayat (2) PP PSBB menyatakan: “Pembatasan Sosial Berskala Besar sebagaimana dimaksud pada ayat (1) harus didasarkan pada pertimbangan epidemiologis, besarnya ancaman, efektifitas, dukungan sumber daya, teknis operasional, pertimbangan politik, ekonomi, sosial, budaya, pertahanan dan keamanan." Rumusan di atas sesuai dengan ketentuan yang diatur dalam Pasal 49 ayat (2) UU KK, yakni :

Karantina rumah, karantina wilayah, karantina rumah sakit, atau pembatasan sosial berskala besar sebagaimana dimaksud pada ayat (1) harus didasarkan pada pertimbangan epidemiologis, besarnya ancaman, efektifitas, dukungan sumber daya, teknis operasional, pertimbangan ekonomi, sosial, budaya, pertahanan dan keamanan.

Hal yang paling nyata menunjukan bahwa PP PSBB ini adalah penyelenggaraan kekarantinaan masyarakat di wilayah adalah dalam ketentuan Pasal 4 ayat (1) PP PSBB yang menyatakan: “Pembatasan Sosial Berskala Besar paling sedikit meliputi:
a. Peliburan sekolah dan tempat kerja
b. Pembatasan kegiatan keagamaan; dan/atau
c. Pembatasan kegiatan di tempat atau fasilitas umum."

Ketentuan tersebut berkeseuaian dengan Pasal 59 ayat (3) UU KK yang memuat klausul yang sama, yakni:

Pembatasan sosial beskala besar sebagaimana dimaksud ayat (1) paling sedikit meliputi

a. Peliburan sekolah dan tempat kerja

b. Pembatasan kegiatan keagamaan; dan/atau

c. Pembatasan kegiatan di tempat atau fasilitas umum.

Dengan memperhatikan perbandiangan di atas, maka dapat dinyatakan bahwa yang dimaksud dengan Pembatasan Sosial Berskala Besar (PSBB) dalam PP PSBB ini adalah ketentuan Pembatasan Sosial Berskala Besar (PSBB) sebagaimana dimaksud dalam penyelenggaraan kekarantinaan kesehatan di wilayah Bab VII UU KK, khususnya dalam Pasal 49 jo 59 jo Pasal 60 UU KK. Pasal 60 UUKK menyebutkan: “Ketentuan lebih lanjut mengenai kriteria dan pelaksanaan Karantina Rumah, Karatina Wilayah, 
Karantiana Rumah Sakit dan Pembatasan Sosial Berskala Besar diatur dengan Peraturan Pemerintah"

Selanjutnya agar PSBB berjalan efektif maka masyarakat harus patuh untuk mendukung pelaksanaan PSBB. ${ }^{15}$ Muhamad Azhar dan Hanna Aulia Azzahra menggambarkan "Good cooperation between the government and the people can also produce good results in order to ward off the COVID-19 pandemic one day."16 (terjemahan bebas: Kerja sama yang baik antara pemerintah dan masyarakat juga dapat menghasilkan hasil yang baik untuk menangkal pandemi COVID-19 suatu hari). Terhadap ketidakpatuhan atau pelanggaran terhadap penyelenggaraan PSBB dapat dijerat dengan sanksi pidana. ${ }^{17}$ Mengingat yang diatur dalam PP PSBB adalah ketentuan Pembatasan Sosial Berskala Besar (PSBB) sebagai penyelenggaraan kekarantinaan kesehatan di wilayah maka sanksi pidana atas pelanggaran terhadap penyelenggaraan kekarantinaan kesehatan i.c Pembatasan Sosial Berskala Besar (PSBB) adalah Pasal 93 UUKK yang selengkapnya menyatakan:

"Setiap orang yang tidak mematuhi penyelenggaraan Kekarantinaan Kesehatan sebagaimana dimaksud dalam Pasal 9 ayat (1) dan/atau menghalang-halangi penyelenggaraan kekarantinaan kesehatan sehingga menyebabkan Kedaruratan Kesehatan Masyarakat dipidana dengan pidana penjara paling lama 1 (satu) tahun dan/atau pidana denda paling banyak Rp. 100.000 .000 (seratus juta rupiah).

Selanjutnya di dalam Pasal 9 ayat (1) UU KK menyatakan: "Setiap orang wajib mematuhi penyelenggaraan Kekarantinaan Kesehatan".

Memperhatikan rumusan Pasal tersebut di atas, senyatanya dapat ditarik unsur yang paling esensial sebagai perbuatan melawan hukum adalah adanya tindakan tidak mematuhi penyelenggaraan kekarantinaan kesehatan dan/atau menghalang-halangi penyelenggaraan kekarantinaan kesehatan sehingga menyebabkan Kedaruratan Kesehatan Masyarakat. Oleh karena dalam hal penangananan Covid 19 Pemerintah telah memilih PSBB sebagai respon untuk menangani Covid 19 maka terkait unsur melawan hukum dalam Pasal 93 UU KK adalah terkait dengan adanya tindakan dari

${ }^{15}$ Adelia Rachma Indriaswari Susanto et al, Tanpa Tahun Terbit, Kajian Politik Hukum Pemerintah dalam Penanganan Pandemi Covid-19, Tanpa Penerbit, Sleman, h. 25.

${ }^{16}$ Muhamad Azhar, 2020, "Government Strategy in Implementing the Good Governance during COVID-19 Pandemic in Indonesia", Administrative Law \& Governance Journal, Nomor 2, Juni 2020, h. 252.

${ }^{17}$ Lihat, Aprista Ristyawati, 2020, "Efektifitas Kebijakan Pembatasan Sosial Berskala Besar Dalam Masa Pandemi Corona Virus 2019 oleh Pemerintah Sesuai Amanat UUD NRI Tahun 1945", Administrative Law E Governance Journal, Nomor 2, Juni 2020, h. 242. 
setiap orang yang tidak mematuhi penyelenggaraan PSBB dan/atau menghalanghalangi penyelenggaraan PSBB sehingga menyebabkan Kedaruratan Kesehatan Masyarakat.

Setelahnya, timbul pertanyaan, apakah dengan paparan di atas, Pasal 93 UU KK sudah serta merta dapat diterapkan? Untuk menjawab pertanyaan tersebut, UU KK telah mengatur bahwa terhadap penetapan PSBB ditetapkan oleh Menteri i.c Menteri Kesehatan sebagaimana diatur dalam Pasal 49 UUKK yang menyatakan: "Karantina Wilayah dan Pembatasan Sosial Berskala Besar sebagaimana dimaksud pada ayat (1) ditetapkan oleh Menteri (Koersif dari Penulis)". Frasa ini menunjukan bahwa dalam hal penyelenggaraan PSBB wajib ditetapkan oleh menteri, a contrario, jika Menteri Kesehatan tidak menetapkan maka penyelenggaraan PSBB tidak dapat diselenggarakan. Terkait dengan penyelenggaraan kekarantinaan di wilayah i.c PSBB, dapat pula dilihat dari PP PSSB (sebagai amanat Pasal $60 \mathrm{KK}$ ), yang mengatur bahwa PSBB oleh Pemerintah Daerah dapat dilakukan setelah ditetapkan oleh Menteri Kesehatan dengan memperhatikan ketentuan sebagaimana yang diatur dalam UU KK 18 dengan kewajiban terlebih dahulu Pemda baik oleh Gubernur/Bupati/ Walikota yang hendak melakukan pemberlakuan PSBB mengusulkan kepada Menteri Kesehatan, selanjutnya Menteri Kesehatan dalam penetapan PSBB memperhatikan pertimbangan Ketua Pelaksana Gugus Tugas Percepatan Penanganan Corona Virus Disease 2019 (Covid-19). Di sisi lain Ketua Pelaksana Gugus Tugas Percepatan Penanganan Corona Virus Disease 2019 (Covid-19) dapat mengusulkan kepada Menteri Kesehatan untuk menetapkan PSBB di wilayah tertentu dan apabila Menteri Kesehatan menyetujui usulan tersebut maka kepada daerah di wilayah tertentu wajib melaksanakan PSBB. ${ }^{19}$ Dengan demikian dapat dinyatakan bahwa untuk penyelenggaraan kekarantinaan kesehatan di wilayah i.c. PSBB di wilayah, ditetapkan oleh Menteri Kesehatan dengan 2 (dua) mekanisme, yakni; mekanisme pemberlakuan PSBB melalui usulan Pemerintah daerah di lingkupnya masing-masing (Gubernur/Bupati/Walikota) kepada Menteri Kesehatan dengan memperhatikan pertimbangan Ketua Pelaksana Gugus Tugas Percepatan Penanganan Corona Virus Disease 2019 (Covid-19) atau atas usulan Ketua Pelaksana Gugus Tugas Percepatan Penanganan Corona Virus Disease 2019 (Covid-19) dengan persetujuan Menteri

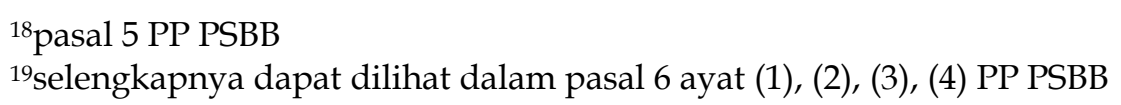


Kesehatan maka Pemerintah daerah di wilayah tertentu wajib menyelenggarakan PSBB. 20

Terdapa beberapa hal pertimbangan yang harus dijadikan dasar oleh Menteri Kesehatan agar suatu wilayah dapat disetujui guna penyelenggaraan PSBB, diantaranya harus didasarkan pada pertimbangan; epidemiologis, besarnya ancaman, efektifitas, dukungan sumber daya, teknis operasional, pertimbangan politik, ekonomi, sosial, budaya, pertahanan dan keamanan. ${ }^{21}$ Selanjutnya PSBB harus memenuhi kriteria (a) jumlah kasus tertentu dan/atau jumlah kematian akibat penyakit meningkat dan menyebar secara signifikan dan menyebar secara signifikan dan cepat ke beberapa wilayah, (b) terdapat kaitan epidemiologis dengan kejadian serupa di wilayah atau negara lain. ${ }^{22}$ Terkait dengan ketentuan permohonan pemberlakukan PSBB oleh: Gubernur/Bupati/Walikota, baik mengenai ruang lingkup maupun data yang wajib disertakan dalam permohonan kepada Menteri Kesehatan telah diatur dalam Pasal 3 jo Pasal 4 Permenkes Pedoman PSBB.

Dengan demikian, berdasarkan penjelasan diatas, maka untuk dapat diselenggarakannya PSBB di wilayah wajib berdasarkan penetapan Menteri Kesehatan dengan dasar pengajuan -dengan kriteria dan permohonan yang telah secara rigidsebagimana diatur baik dalam PP PSBB dan/atau oleh Permenkes Pedoman PSBB. Artinya, secara hukum, keabsahan pemberlakukan PSBB di suatu wilayah diakui bila telah memenuhi amanat UU KK, Jo PP PSBB jo. Permenkes Pedoman PSBB, yakni: adanya penetapan dari Menteri Kesehatan, baik yang berasal dari pengajuan oleh Pemerintah Daerah (Gubernur/Bupati/Walikota) sesuai dengan ruang lingkupnya maupun berdasarkan usulan Ketua Pelaksana Gugus tugas Percepatan Penanganan Corona Virus Disease 2019 (Covid-19), tentu saja semuanya terlebih dahulu wajib ada penetapan darurat kesehatan masyarakat oleh Presiden. Oleh karenanya dapat dinyatakan bahwa Pasal 93 UU KK hanya dapat diterapkan jika sudah ada penetapan pemberlakukan PSBB di suatu wilayah tertentu oleh Menteri Kesehatan.

Berkaitan dengan kasus adanya pelaksanaan prosesi ngaben massal Dadia Pasek Kubayan, di Desa Sudaji, Kecamatan Sawan Kabupaten Buleleng Provinsi Bali yang dilakukan pada 1 April 2020, halmana ditetapkannya Made Suwardana (Ketua Panitia

${ }^{20}$ lihat pasal 6 PP PSBB jo pasal 4 jo pasal 5 Permenkes pedoman PSBB

${ }^{21}$ lihat pasal 2 ayat (2) PP PSBB jo. Pasal 2 Permenkes Pedoman PSBB

22lihat pasasl 3 PP PSBB juncto Pasal 2 Permenkes Pedoman PSBB 
Pelaksana) sebagai Tersangka oleh Penyidik, terdapat beberapa hal yang patut diperhatikan untuk selanjutnya dapat menjawab, apakah Pasal 93 UU KK dapat diterapkan di daerah Bali? Berdasarkan peraturan hukum perundang-undangan yang mengatur mengenai penyelenggaraan PSBB sebagai respon kedaruratan kesehatan masyarakat di wilayah, telah diuraikan bahwa salah satu yang menjadi tolak ukur keabsahan penyelenggaraan PSBB di wilayah i.c di wilayah Bali adalah adanya penetapan penyelenggaraan PSBB oleh Menteri Kesehatan, baik melalui pengajuan oleh kepala daerah Gubernur Bali, maupun oleh Bupati/Walikota se-Bali atau adanya penetapan Menteri Kesehatan atas dasar usulan dari Ketua Pelaksana Gugus Tugas Percepatan Penanganan Corona Virus Disease 2019 (Covid-19). Berdasarkan penelusuran yang dilakukan, mulai dari adanya penetapan darurat kesehatan masyarakat oleh Presiden Joko Widodo hingga 22 April 2020, berdasarkan pernyataan $\mathrm{BNPB}$, terdapat 2 (dua) provinsi dan 21 (dua puluh satu) kabupaten/kota yang telah menyelenggarakan PSBB dan ada 7 (tujuh) daerah lainnya yang sedang dalam melengkapi persyaratannya. ${ }^{23}$ Namun demikian, hingga tulisan ini disusun, tidak ada satupun pemerintah daerah di Bali baik provinsi maupun kabupaten/kota yang menyelenggarakan PSBB, bahkan tidak ada satupun yang mengajukan usul untuk penyelenggaran PSBB di daerahnya. Pemerintah Provinsi Bali dalam menyikapi situasi pandemi ini, merespon situasi dengan menerbitkan beberapa kebijakan, yakni; Keputusan Gubernur Bali Nomor 258/04-G/HK/2020 tentang Penetapan Status Siaga Darurat Bencana Akibat Wabah Penyakit Corona Di Provinsi Bali pada 16 Maret 202024, kemudian diperpanjang melalui surat nomor: 272/04-G/HK/2020 tentang Perpanjangan Status Siaga Darurat Bencana Akibat Wabah Penyakit Virus Corona di Provinsi Bali. ${ }^{25}$ Status tersebut ditingkatkan menjadi status tanggap darurat bencana

23 lihat https://nasional.kompas.com/read/2020/04/22/19520061/bnpb-sudah-2provinsi-dan-21-kabupaten-kota-yang-terapkan-psbb, diakses pasa 27 mei 2020 , pada pukul 20.30 wita.

24 lihat https://www.vivanews.com/berita/nasional/40702-pemprov-bali-tetapkanstatus-siaga-penanggulangan-corona-covid-19?medium=autonext, diakses pada 27 mei 2020 , pada pukul 20.31 wita; lihat juga: https://jarrakpos.com/16/03/2020/perangi-covid-19gubernur-koster-tetapkan-status-bali-siaga-penanggulangan-covid-19/, diakses pada 27 mei 2020 , pada pukul 20.31 wita; lihat juga https://bali.tribunnews.com/2020/03/16/breakingnews-pemprov-bali-tetapkan-status-siaga-dalam-penanggulangan-covid-19, diakses pada 27 mei 2020 , pada pukul 20.31 wita; lihat https://kumparan.com/kumparannews/gubernur-balitetapkan-status-siaga-corona-kegiatan-agama-di-rumah-saja-1t2N2XasVSb/full, diakses pada 27 mei 2020 , pada pukul 20.31 wita;

25ditetapkan pada 31 maret 2020 yang berlaku sampai 31 mei 2020 
melalui Surat Keputusan Gubernur Bali Nomor 270/04-G/HK/2020 tentang Penetapan Status Darurat Tanggap Bencana Wabah Penyakit Akibat Virus Corona-19 di Propinsi Bali26, dan diperpanjang melalui Keputusan Gubernur Bali Nomor 303/04G/HK/2020 tentang Penetapan Perpanjangan Status Darurat Tanggap Bencana Wabah Penyakit Akibat Virus Corona-19 di Propinsi Bali. Selanjutnya guna menindaklanjuti keputusan pemerintah terkait dengan penetapan darurat kesehatan masyarakat jo. PSBB, Gubernur Bali, I Wayan Koster juga menerbitkan surat Instruksi Gubernur Nomor 8551 Tahun 2020 tentang Penguatan, Pencegahan dan Penanganan Covid 19 di Bali. Instruksi Gubernur tersebut mendasarkan pada PP PSBB, Keppres Nomor 11 Tahun 2020, Maklumat Kapolri Nomor: Maks/2/III/2020 dan Keputusan Gubernur Bali Nomor 270/04-G/HK/2020. Pemerintah Provinsi Bali maupun Pemerintah Kabupaten/Kota tidak ada yang menyelenggarakan kekarantinaan kesehatan berupa PSBB dan tidak ada pula yang mengajukannya. Bahkan Pemerintah Provinsi Bali telah menegaskan berulangkali bahwa mereka tidak menerapkan PSBB guna menanggulangi Covid,27 namun mereka mengakui bahwa mereka menerapkan subtansi PSBB dalam praktek penanggulangan wabah ini, ${ }^{28}$ bahkan mengklaim sukses menanggulangi wabah Covid 19 tanpa perlu menyelenggarakan PSBB. ${ }^{29}$

Atas dasar hal demikian maka dapat dinyatakan bahwa Pemerintah Provinsi Bali tidak pernah secara hukum menyelenggarakan PSBB sebagaimana ketentuan yang

26 https://www.vivanews.com/berita/nasional/43105-wabah-corona-nbsp-menggilabali-tetapkan-status-tanggap-darurat?medium=autonext diakses [ada 27 mei 2020 pukul 2045 wita. Lihat juga https://www.merdeka.com/peristiwa/pemprov-bali-tetapkan-statustanggap-darurat-covid-19.html, diakses [ada 27 mei 2020 pukul 2045 wita,

27 https://mediaindonesia.com/read/detail/308807-bali-bersikukuh-tolak-ajukan-psbb

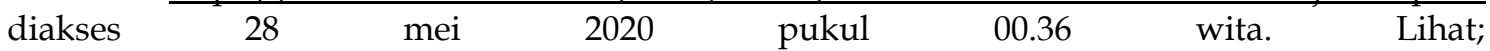
https://www.nusabali.com/berita/72379/gubernur-koster-belum-memperhitungkanpenerapan-psbb-di-bali, diakses 28 mei 2020 pukul 00.36 wita.

28 https://radarbali.jawapos.com/read/2020/04/29/191561/soal-psbb-di-bali-dewaindra-secara-substansi-sudah-lakukan diakses 28 mei 2020 pukul 00.36 wita. Lihat;https://kumparan.com/kumparannews/pemprov-bali-soal-pp-psbb-sudah-diterapkanbahkan-lebih-luas-1t8j0DbOoXd, diakses 28 mei 2020 pukul 00.36 wita.

29 https://bali.tribunnews.com/2020/05/10/3-indikator-bali-lebih-efektif-kendalikanpenyebaran-covid-19-dibanding-daerah-lain-terapkan-psbb, diakses 28 Mei 2020 pukul 00.43 wita. Lihat; https://news.detik.com/berita/d-5012616/ini-strategi-bali-berhasil-lawan-coronatanpa-psbb diakses pada 28 mei 2020 , pukul 00.44 wita. Lihat; https://www.liputan6.com/regional/read/4247452/tanpa-psbb-bali-klaim-sukses-atasicorona, pada 28 mei 2020 , pukul 00.44 wita; LIhat; https://www.tribunnews.com/corona/2020/05/10/ini-strategi-yang-dipakai-gubernur-balihingga-sukses-kendalikan-penyebaran-covid-19-tanpa-psbb , diakses 28 Mei 2020 pukul 00.44 wita 
diatur oleh peraturan perundang-undangan yang mengatur mengenai kekarantinaan kesehatan c.q PSBB. Demikian pula, hingga adanya penetapan tersangka dalam kasus ngaben dimaksud, tidak ada satupun penetapan penyelenggaraan PSBB di wilayah Provinsi Bali yang ditetapkan oleh Menteri Kesehatan berdasarkan usulan dari Ketua Pelaksana Gugus Tugas Percepatan Penanganan Corona Virus Disease 2019 (Covid-19). Sehingga ditilik dari lingkup penyelenggaraan PSBB berdasarkan permohonan Gubenur, -halmana lingkup yang dimaksud adalah untuk lingkup provinsi atau kabupaten/kota tertentu- maka senyatanya tidak ada penyelenggaraan PSBB sebagaimana dimaksud termasuk di Kabupaten Singaraja. 30 Demikian pula, berdasarkan penelusuran hukum terhadap penetepan tersangka pada kasus ngaben tersebut, tidak ada satupun penetapan dari Menteri Kesehatan untuk penyelenggaraan PSBB yang didasarkan atas pengajuan usul dari Bupati yang melingkupi satu kabupaten i.c. Bupati Buleleng untuk lingkup Kabupaten Buleleng, ${ }^{31}$ pun tidak ada penetapan penyelenggaran PSBB oleh Menteri Kesehatan di Kabupaten Buleleng berdasarkan usulan dari Ketua Pelaksana Gugus Tugas Percepatan Penangaan Corona Virus Disease 2019 (Covid-19).

Dengan mendasarkan pada akta-fakta tersebut di atas maka Peulis berpendapata bahwa penetapan Tersangka dengan menggunakan Pasal 93 UU KK oleh Penyidik Polres Buleleng terhadap Made Suwardana adalah penetapan yang tidak tepat hukum karena berdasarkan norma hukum senyatanya Pasal 93 UU KK hanya dapat diterapkan pada wilayah yang telah memberlakukan penyelenggaraan PSBB berdasarkan penetapan Menteri Kesehatan sesuai ketentuan peraturan perundang-undangan. Tentu saja sangat tidak logis bilamana seseorang diminta pertanggungjawaban hukum melakukan perbuatan melawan hukum berupa tindakan yang tidak mematuhi penyelenggaraan kekarantinaan kesehatan i.c. PSBB dan/atau menghalang-halangi penyelenggaraan kekarantinaan kesehatan i.c PSBB sementara di daerah tersebut belum ditetapkannya penyelenggaraan PSBB oleh Menteri Kesehatan sesuai peraturan perundang-undangan.

Hal lain terkait dengan penerapan Pasal 93 UU KK ditinjau dari perspektif ruang lingkup delik. Jika menilik Pasal 39 UU KK dari ruang lingkup delik, yakni

${ }^{30}$ Lihat Pasal 3 ayat (2) Permenkes Pedoman PSBB

31lihat pasal 3 ayat (3) Permenkes Pedoman PSBB 
:delik formil dan delik materiil dapat dinyatakan sebagai berikut; Berdasarkan pendapat Sudarto mengenai delik formil dan delik materiil:

a. Delik formil itu adalah delik yang perumusanya dititik beratkan kepada perbuatan yang dilarang. Delik tersebut telah selesai dengan dilakukanya perbuatan seperti tercantum dalam rumusan delik. Pada delik formil, suatu akibat tertentu hanya dapat memberatkan atau meringankan pidana, tetapi juga tanpa akibat perbuatan itu sendiri sudah dilarang dan dapat dipidana.

b. Delik formil itu adalah delik materiil adalah delik yang perumusannya dititik beratkan kepada akibat yang tidak dikehendaki (dilarang). Delik itu baru selesai, apabila akibat yang tidak dikehendaki itu telah terjadi kalau belum maka paling banyak hanya ada percobaan. Pada delik materiil kita berbicara tentang akibat "konstitutif". 32

Dengan memperhatikan rumusan Pasal 93 UU KK, hal mana terdapat frasa "sehingga menyebabkan Kedaruratan Kesehatan Masyarakat" maka dapat dimaknai bahwa dalam rumusan tersebut adalah menitikberatkan pada akibat yang tidak dikehendaki (dilarang) menyebabkan kedaruratan kesehatan masyarakat maka delik yang terkandung dalam Pasal tersebut dapat dinyatakan sebagai delik materiil. Oleh karena Pasal 93 UU KK adalah merupakan delik materiil, maka atas tindak pidana yang dilakukan oleh setiap orang hanya dapat dipidana setelah tindakan yang dilakukan baik tidak mematuhi penyelenggaraan PSBB dan/atau menghalang-halangi penyelenggaraan PSBB tersebut menimbulkan akibat kedarutan kesehatan masyarakat dan jika tidak ada akibat yang ditimbulkan maka terhadap tindakan tersebut tidak dapat dipidana.

Adapun dimaksud dengan "kedaruratan kesehatan masyarakat" diatur dalam Pasal 1 angka 2 UU KK, yang menyebutkan: “Kejadian kesehatan masyarakat yang bersifat luar biasa dengan ditandai penyebaran penyakit menular dan/atau kejadian yang disebabkan oleh radiasi nuklir, pencemaran biologi, kontaminasi kimia, bioterorisme, dan pangan yang menimbulkan bahaya kesehatan dan berpotensi menyebar lintas wilayah atau lintas negara." Artinya pelanggaran PSBB dalam bentuk tidak mematuhi dan/atau menghalang-halangi penyelenggaraan PSBB dapat dipidana hanya apabila mengakibatkan kejadian kesehatan masyarakat yang luar biasa ditandai dengan penyebaran penyakit menular yang berpotensi menyebar lintas wilayah atau lintas negara.

32Sudarto, 1990, Hukum Pidana I, Cet-2, Yayasan Sudarto Undip, Semarang, h. 56 
Berdasarkan hal tersebut untuk menerapkan Pasal 93 UU KK, pihak penegak hukum i.c Penyidik Polres Buleleng patut memperhatikan mengenai ruang lingkup delik Pasal tersebut. Mengingat bahwa Pasal 93 UU KK adalah delik materiil maka mensyaratkan adanya akibat berupa timbulnya kedaruratan kesehatan masyarakat agar delik dapat dinyatakan sebagai delik yang telah selesai. Penyidik sepatutnya melakukan penyidikan dengan serius terhadap fakta-fakta hukum terkait dengan akibat yang ditimbulkan dari ada penyelenggaraan ngaben terutama terkait dengan menyebabkan kedaruratan masyarakat. Ketidakhati-hatian Penyidik atas hal tersebut dapat menyebabkan penerapan Pasal 93 UU KK tidak tepat karena belum dapat ditemukannya akibat yang ditimbulkan dari kegiatan ngaben tersebut terhadap kedaruratan kesehatan masyarakat.

Jikapun dalam kasus penyelenggaraan ngaben tersebut telah terpenuhinya delik materiil dalam arti telah ternyata penyelenggaraan ngaben tersebut dapat dibuktikan menimbulkan akibat yang menyebabkan kedaruratan kesehatan masyarakat sehingga delik dapat dinyatakan telah selesai, maka tidak serta merta pasal 93 UU KK dapat diberlakukan. Hal ini mengingat bahwa syarat utama dari penerapan delik tersebut adalah adanya penyelenggaraan PSBB sesuai dengan ketentuan yang diatur oleh UU KK jo. PP PSBB jo Permenkes Pedoman PSBB. Oleh karenanya secara hukum, dalam kasus pengabenan dimaksud, kendati Penyidik telah menemukan bukti yang menyatakan bahwa telah terjadi akibat kedaruratan kesehatan masyarakat akibat penyelenggaraan kegiatan ngaben tersebut, namun oleh karena di wilayah lingkup Provinsi Bali belum ditetapkan penyelenggaraan PSBB oleh Menteri Kesehatan sebagaimana ketentuan peraturan perundang-undangan, maka pasal 93 UU KK tidak dapat diberlakukan. Dengan demikian, penetapan tersangka terhadap Made Suwardana, Ketua Panitia Pelaksana ngaben massal Dadia Pasek Kubayan, di Desa Sudaji, Kecamatan Sawan Kabupaten Buleleng Provinsi Bali tidak sah hukum.

Selanjutnya, terkait dengan adanya Maklumat Kapolri Nomor Mak/2/III/2020 tentang Kepatuhan Terhadap Kebijakan Pemerintah Dalam Penanganan Penyebaran Covid-19, dimana Maklumat Kapolri No. Mak/2/III/2020 tersebut mengamanatkan pihak kepolisian untuk melakukan penegakan hukum terhadap 
masyarakat yang tidak mengindahkan himbauan PSBB. ${ }^{33}$ Demikian pula dengan imbauan Pemerintah Daerah mengenai berbagai pembatasan kegiatan masyarakat sebagaimana yang termaktub dalam Instruksi Gubernur Nomor 8551 tahun 2020 yang dijadikan dasar penetapan tersangka akan dibahas dan analisa. Dalam menganalisa dasar penetapan tersebut, tentu pertanyaan penting yang timbul adalah; apakah pelanggaran atas Maklumat Kapolri dan imbauan pemerintah daerah dapat menjadi dasar penerapan pasal 93 UU KK?

Sebelum membahas hal tersebut, akan dibahas mengenai posisi hukum dari Maklumat Kapolri no. Mak/2/III/2020 dan Instruksi Gubernur Bali Nomor 8551 tahun 2020 yang menjadi dasar imbauan kepada rakyat Bali dalam penanganan Covid 19. Bilamana mengacu kepada teori hukum mengenai teori hukum tata pemerintahan maka maklumat Kapolri dan instruksi Gubenur Bali tersebut termasuk dalam kualifiaksi legislasi semu. Legislasi semu memberikan kewenangan bagi pemerintah untuk membuat peraturan untuk menjalankan tugas umum pemerintahan. ${ }^{34}$

Adapun pengertian dari legislasi semu menurut Kamus Hukum Bahasa Belanda istilah Pseudowetgeving (legislasi semu) berarti regelstelling door een betrokken bestuursorgaan zonder dat dit op grond van een uitdrukkelijke wettelijke bepaling die bevoegdheid bezit. 35 (Perundang-undangan semu adalah tata aturan oleh organ pemerintahan yang terkait tanpa memiliki dasar ketentuan undang-undang yang secara tegas memberikan kewenangan kepada organ tersebut). Peraturan kebijaksanaan terkait dengan pelaksanaan pemerintahan sehari-hari yang menunjukkan betapa badan atau pejabat tata usaha negara acapkali menempuh pelbagai langkah kebijaksanaan tertentu, antara lain menciptakan apa yang kini sering dinamakan peraturan kebijaksanaan (beleidsregels, policy rule). Produk semacam peraturan kebijaksanaan ini tidak terlepas dari kaitan penggunaan freies Ermessen, yaitu, badan atau pejabat tata usaha negara yang bersangkutan merumuskan kebijaksanaannya itu dalam pelbagai bentuk "juridische regels", seperti halnya peraturan, pedoman, pengumuman, surat edaran, dan mengumumkan kebijaksanaan

${ }^{33}$ Lihat, Nur Rohim Yunus, 2020, "Kebijakan Covid-19, Bebaskan Narapidana dan Pidanakan Pelanggar PSBB", 'ADALAH, Nomor 1, 2020, h. 4.

${ }^{34}$ Nehru Asyikin, 2020, "Pengujian Freies Ermessen Atas Legislasi Semu Kepala Daerah", JURNAL HUKUM EKONOMI SYARIAH, Volume 3, Nomor 1, April 2020, h. 81.

${ }^{35}$ Andreae's Fockema, 1985, Juridisch Woordenboek, Tjeenk Willink, h. 396 
itu. ${ }^{36}$ Meskipun demikian, pemerintah dilarang membuat kebijakan detournement de pouvoir (melakukan sesuatu di luar tujuan kewenangan yang diberikan). ${ }^{37}$

Menurut Bagir Manan, seperti dikutip oleh Ridwan HR, peraturan kebijaksanaan (legislasi semu) mempunyai ciri-ciri sebagai berikut: ${ }^{38}$

1. Peraturan kebijaksanaan bukan merupakan peraturan perundang-undangan;

2. Asas-asas pembatasan dan pengujian terhadap peraturan perundangundangan tidak dapat diberlakukan pada peraturan kebijaksanaan;

3. Peraturan kebijaksanaan tidak dapat diuji secara wetmatigheid, karena memang tidak ada dasar peraturan perundang-undangan untuk membuat keputusan peraturan kebijaksanaan tersebut;

4. Peraturan kebijaksanaan dibuat berdasarkan freies Ermessen dan ketiadaan wewenang administrasi bersangkutan membuat peraturan perundangundangan;

5. Pengujian terhadap peraturan kebijaksanaan lebih diserahkan kepada doelmatigheid sehingga batu ujinya adalah asas-asas umum pemerintahan yang layak;

6. Dalam praktik diberi format dalam berbagai bentuk dan jenis aturan, yakni keputusan, instruksi (huruf tebal dari Penulis), surat edaran, pengumuman (huruf tebal dari Penulis) dan lain-lain, bahkan dapat dijumpai dalam bentuk peraturan.

Dalam praktek pemerintahan sehari-hari legislasi semu dapat diterbitkan oleh semua badan atau organ pemerintahan baik di tingkat pusat maupun daerah. Umumnya format dan nomenklatur yang dipakai untuk legislasi semu berbeda dengan peraturan perundang-undangan, walaupun dapat pula dijumpai substansi legislasi semu dituangkan dalam format perundang-undangan. Tidak ada suatu format baku yang digunakan dalam pembentukan legislasi semu. Bagir Manan menyebutkan bahwa aturan kebijakan bukan peraturan perundang-undangan dan tidak langsung mengikat secara hukum, tetapi mengandung relevansi hukum.

a) Terhadap pelanggaran Maklumat Kapolri No. Mak/2/III/2020

Maklumat Kapolri tersebut dikeluarkan pada tanggal 19 Maret 2020, untuk diketahui dan dipatuhi oleh seluruh masyarakat ${ }^{39}$ dengan mempertimbangkan situasi nasional terkait dengan cepatnya penyebaran Covid-19 halmana pemerintah telah

36Philipus M. Hadjon et al, 2002, Pengantar Hukum Administrasi Indonesia, Gadjahmada University Press, Yogyakarta, h. 153

${ }^{37}$ Radita Ajie. 2018, "Batasan pilihan kebijakan pembentuk undang-undang (Open legal policy) dalam pembentukan peraturan perundang-undangan berdasarkan tafsir Putusan Mahkamah Konstitusi", Jurnal Legislasi Indonesia, Nomor 2, Mei 2018, h. 113.

38Ridwan HR, 2006, Hukum Administrasi Negara, Raja Grafindo, Jakarta, h. 186

${ }^{39}$ Lihat angka 4 Maklumat Kapolri no. Mak/2/III/2020 
mengeluarkan kebijakan dalam rangka penanganan secara baik, cepat, dan tepat agar penyebarannya tidak meluas dan berkembang menjadi gangguan terhadap keamanan dan ketertiban masyarakat. Selanjutnya untuk memberikan perlindungan kepada masyarakat, dengan mengacu pada asas keselamatan rakyat merupakan hukum tertinggi (Salus Populi Suprema Lex Esto). ${ }^{40}$ Pada pokoknya terdapat beberapa pembatasan yang dimuat dalam Maklumat tersebut dimuat dalam angka 2 huruf a s/d huruf c yang menyatakan sebagai berikut:

2) Bahwa untuk memberikan perlindungan kepada masyarakat, Polri senantiasa mengacu asas keselamatan rakyat merupakan hukum tertinggi (Salus Populi Suprema Lex Esto), dengan ini Kepala Kepolisian Negara Republik Indonesia mengeluarkan Maklumat:

a. tidak mengadakan kegiatan sosial kemasyarakatan yang menyebabkan berkumpulnya massa dalam jumlah banyak, baik di tempat umum maupun di lingkungan sendiri, yaitu:

1) pertemuan sosial, budaya, keagamaan dan aliran kepercayaan dalam bentuk seminar, lokakarya, sarasehan dan kegiatan lainnya yang sejenis;

2) kegiatan konser musik, pekan raya, festival, bazaar, pasar malam, pameran, dan resepsi keluarga;

3) kegiatan olah raga, kesenian, dan jasa hiburan;

4) unjuk rasa, pawai, dan karnaval; serta

5) kegiatan lainnya yang menjadikan berkumpulnya massa.

b. tetap tenang dan tidak panik serta lebih meningkatkan kewaspadaan di lingkungan masing-masing dengan selalu mengikuti informasi dan imbauan resmi yang dikeluarkan oleh pemerintah;

c. apabila dalam keadaan mendesak dan tidak dapat dihindari, kegiatan yang melibatkan banyak orang dilaksanakan dengan tetap menjaga jarak dan wajib mengikuti prosedur pemerintah terkait pencegahan penyebaran Covid-19;

Selanjutnya mengenai konsekuensi dari apabila ditemukan perbuatan yang bertentangan dengan Maklumat ini, diatur dalam angka 3 Maklumat yang selengkapnya menyatakan sebagai berikut: "apabila ditemukan perbuatan yang bertentangan dengan Maklumat ini, maka setiap anggota Polri wajib melakukan

${ }^{40}$ Lihat angka 1 dan angka 2 Maklumat Kapolri no. Mak/2/III/2020. Lihat juga: https://www.cnnindonesia.com/nasional/20200326172515-20-487231/dasar-maklumat-

kapolri-keselamatan-rakyat-hukum-tertinggi diakses pada 6 Juni 2020 pukul 16.40 wita. Lihat juga https://nasional.kontan.co.id/news/ini-isi-maklumat-kapolri-dalam-penangananpenyebaran-virus-corona diakses pada 6 Juni 2020 pukul 16.42 wita. Lihat: https://tirto.id/cegah-corona-polisi-akan-tindak-tegas-warga-tetap-buat-keramaian-eG7o, diakses pada diakses pada 6 Juni 2020 pukul 16.43 wita. 
tindakan kepolisian yang diperlukan sesuai ketentuan peraturan perundang-undangan yang berlaku."

Terhadap hal tersebut terlebih dahulu akan dibahas mengenai posisi hukum maklumat Kapolri tersebut. Mengenai defisini dari Maklumat Kapolri, tidak ada definisi yang ditemukan dalam peraturan perundang-undangan. Menurut Kamus Besar Bahasa Indonesia (KBBI) yang ${ }^{41}$ dimaksud dengan maklumat adalah

maklumat/mak-lu-mat/ $n 1$ pemberitahuan; pengumuman: rakyat menyambut -itu dengan gembira; 2 pengetahuan; mualamat: mereka tidak mempunyai -- yang cukup atas segala hal yang bersangkut paut dengan perkataan itu;

--pemerintah Pol pengumuman yang dikeluarkan oleh pemerintah, misalnya maklumat tanggal 14 November 1945 tentang perubahan pertanggungjawaban menteri, yakni tidak lagi kepada presiden, tetapi kepada Badan Pekerja Komite Nasional Indonesia Pusat;

-- presiden Pol pengumuman yang dikeluarkan oleh presiden, misalnya maklumat tanggal 29 Juni 1959 tentang pengambilan kembali kekuasaan pemerintahan oleh presiden dari tangan kabinet;

memaklumatkan /memaklumatkan me-mak-lu-mat-kan / $v$ memberitahukan; memaklumkan; mengeluarkan maklumat.

Dengan merujuk pada pengertian maklumat dalam KBBI maka dapat dinyatakan bahwa maklumat adalah pemberitahuan atau pengumuman kepada rakyat. Dalam konteks Maklumat Kapolri maka dapat diartikan bahwa Maklumat Kapolri adalah pengumuman yang dikeluarkan oleh Kepala Kepolisian Republik Indonesia. Oleh karenanya pada dasarnya maklumat tersebut adalah pengumanan maka berdasarkan pendapat Bagir Manan, seperti dikutip oleh Ridwan HR, mengenai ciri-ciri dari peraturan kebijaksanaan (legislasi semu) di atas, maka maklumat ini dapat dikualifikasi sebagai legislasi semu. Oleh karenanya tidak mempunyai kekuatan mengikat hanya relevansi hukum.

Menurut Muhammad Fauzan maklumat mengandung pengertian pengumuman atau pemberitahuan untuk diketahui khalayak yang tidak memiliki kekuatan mengikat. Apabila maklumat itu berkaitan dengan hukum, maka sudah memiliki kekuatan mengikat. Fauzan menyatakan: "Polri kalau tidak salah pernah memberikan batasan mengenai terminologi 'Maklumat' yakni pemberitahuan mengenai berlakunya suatu peraturan yang di dalamnya memuat sanksi hukum yang

${ }^{41}$ https://kbbi.web.id/maklumat diakses pada diakses pada diakses pada 6 Juni 2020 pukul 16.50 wita. 
berlaku bagi siapa saja yang tidak mau menaati atau menjalankan apa yang dimaksudkan dalam maklumat tersebut." 42

Bilamana mengacu pada ketentuan angka 3 Maklumat Kapolri tersebut, maka terdapat kewajiban bagi anggota Polri untuk melakukan tindakan kepolisian yang diperlukan sesuai ketentuan peraturan perundangundangan yang berlaku apabila ditemukan perbuatan yang bertentangan dengan Maklumat ini. Dengan demikian, maka dapat diartikan bahwa penegakan hukum atas penyimpangan terhadap maklumat Kapolri adalah sesuai dengan ketetentuan Peraturan Perundang-Undangan terutama terkait dengan penanggulangan Covid -19. Lantas bagaimana dengan penerapan pasal 93 UU KK dihubungkan dengan maklumat ini?

Secara normatif, penerapan Pasal 93 UU KK tidak serta merta dapat dilakukan jika terdapat tindakan yang bertentangan dengan maklumat Kapolri tersebut karena penindakan hukum yang dilakukan harus sesuai Peraturan Perundang-Undangan. Logika hukumnya adalah; dalam hal penerapan sanksi pidana sebagaimana diatur dalam Pasal 93 UU KK maka tidak boleh dilakukan di luar ketentuan Peraturan Perundang-Undangan, halmana mengenai penerapan pasal 93 UU KK tersebut wajib didahului dengan adanya penetapan kedaruratan kesehatan masyarakat dan adanya respon tindakan kekarantinaan yang ditetapkan dari pemerintah c.q Presiden. Dalam hal penanganan Covid -19, bila ada tindakan setiap orang yang bertentangan dengan isi Maklumat Kapolri tersebut, maka tidak serta merta tindakan yang bertentangan dengan Maklumat Kapolri tersebut dapat dipidana dengan menerapkan Pasal 93 UU KK, halmana bilamana di wilayah tersebut belum ada penetapan pemberlakukan PSBB oleh Menteri Kesehatan sebagaimana yang diatur oleh Peraturan PerundangUndangan maka sekalipun ada tindakan yang bertentangan dengan isi Maklumat Kapolri tersebut maka pasal 93 UU KK tidak dapat diberlakukan. Oleh karenanya, argumentasi yang menyatakan bahwa penetapan tersangka; Made Suwardana, Ketua Panitia Pelaksana ngaben massal melanggar Maklumat Kapolri sebagai alas hukum adalah argumentasi hukum tidak tepat hukum dan merupakan tindakan penegakan hukum yang tidak sah hukum.

42 Lihat https://www.tagar.id/maklumat-kapolri-soal-pembubaran-perkumpulandisoroti, diakses pada 6 Juni 2020, pukul 17.14 wita 
b) Terhadap pelanggaran Instruksi Gubenur Bali Nomor 8551 Tahun 2020.

Sebagaimana yang telah disampaikan diatas, sampai saat tulisan ini disusun, Pemerintah Daerah Provinsi Bali termasuk Pemerintah Daerah Kabupaten/Kota di Bali tidak ada satupun yang mengajukan usulan pemberlakukan PSBB di wilayahnya dan tidak ada pula penetapan oleh Menteri Kesehatan untuk penyelengggaraan PSBB di lingkup wilayah Pemerintah Daerah Provinsi Bali dan/atau Pemerintah Kabupaten/Kota di Bali. Kebijakan Pemerintah Provinsi Bali yang terkait langsung dengan pembatasan aktifitas masyarakat dalam upaya penanganan covid-19 adalah melalui Instuksi Gubernur Nomor 8551 Tahun 2020 tentang Penguatan, Pencegahan dan Penanganan Covid 19 di Bali. Instruksi Gubernur tersebut mendasarkan pada PP PSBB, Keppres Nomor 11 Tahun 2020, Maklumat Kapolri Nomor: Mak/2/III/2020 dan Keputusan Gubernur Nomor 270/04-G/HK/2020. Instruksi tersebut ditujukan kepada: (1) Bupati/Walikotta se Bali, (2) Parisada Hindu Dharma Indonesia se-Bali, (3) Majelis Desa Adat se-Bali, (4) Kepala Lembaga Layanan Pendidikan Tinggi Wilayah VIII, (5) Kepala Otoritas Bandata Wilayah IV, (6) Kepala KSOP Benoa, (7) Kepala KSOP Gilimanuk, (8) Kepala KSOP Padang Bai, (9) Kepala KSOP Celukan Bawang, (10) Kepala Balai Penyelengggaraan Transportasi Darat Wilayah XII. Pada pokoknya instruksi Gubernur tersebut memuat instruksi, diantaranya: Diktum Kesatu; memperkuat pembatasan aktifitas warga di luar rumah baik belajar di rumah, bekerja di rumah dan beribadah di rumah. Diktum Kedua; memperkuat pembatasan kegiatan keramaian dan obyek wisata. Diktum Ketiga; pembatasan kegiatan adat dan agama (huruf tebal dan garis bawah dari Penulis). Diktum Keempat; memperkuat pembatasan masyarakat melakukan perjalanan keluar dan/atau masuk ke Bali. Diktum kelima; Otoritas Bandara dan Otoritas Pelabuhan agar meningkatkan pengawasan dan seleksi secara ketat terhadap perlintasan orang dan/atau penumpang sesuai protokol masuk.

Kasus ngaben massal didalilkan melanggar instruksi Gubernur Bali ini, khususnya didalilkan melanggar mengenai batasan penyelenggaraan kegiatan adat dan agama yang dilakukan di luar rumah sebagaimana yang diatur dalam Diktum Ketiga, Instruksi Gubernur Bali yang selengkapnya menyatakan sebagai berikut:

Diktum Ketiga: Memperkuat pembatasan kegiatan dan agama:

a. Kegiatan adat dan agama agar dilaksanakan di rumah; 
b. Dalam hal kegiatan adat dan agama harus dilakukan di luar rumah, hanya melibatkan paling banyak 25 (dua puluh lima) orang, dengan menerapkan jarak fisik dan perilaku hidup bersih dan sehat (PHBS).

Penyelenggaraan ngaben tersebut didalilkan melibatkan orang lebih dari ketentuan Instruksi Gubernur Bali -yakni; 25 (dua puluh lima) orang- tersebut sehingga selanjutnya diproses hukum dan ditetapkan sebagai tersangka. Dengan memperhatikan bahwa Instruksi Gubernur Bali ini selanjutnya dihubungkan dengan pendapat Bagir Manan, seperti dikutip oleh Ridwan HR, mengenai ciri-ciri dari peraturan kebijaksanaan (legislasi semu) di atas, maka Instruksi Gubernur Bali ini dapat dikualifikasi sebagai legislasi semu. Oleh karenanya instruksi Gubernur Bali tersebut tidak langsung mengikat secara hukum, tetapi mengandung relevansi hukum. Selanjutnya apakah pelanggaran terhadap Instruksi Gubernur Bali serta merta dapat digunakan untuk mempidana orang yang melanggar instruksi tersebut? Lebih rigidnya apakah pelanggaran atas ketentuan instruksi Gubernur Bali merupakan tindakan pidana sehingga bisa dipidana dengan pasal 93 UU KK?

Pelanggaran terhadap Instruksi Gubernur Bali tersebut tidak dapat dipidana, selain karena Instruksi Gubernur Bali tersebut adalah merupakan legislasi semu sehingga tidak mempunyai kekuatan hukum mengikat dan hanya mengandung relevansi hukum, hal lain adalah jika dikaitkan penerapan pasal 93 UU KK maka pelanggaran atas instruksi Gubernur Bali tersebut tidak ada kaitan hukumnya penyelenggaraan PSBB karena instruksi Gubernur Bali tersebut bukanlah instrumen penyelenggaraan PSBB. Sebagaimana telah diulas sebelumnya, secara hukum, penerapan Pasal 93 UU KK hanya dapat diterapkan pada wilayah yang memberlakukan penyelenggaraan PSBB sesuai ketentuan hukum dan perundangundangan halmana Pasal 93 UU KK hanya dapat diterapkan terhadap tindakan yang tidak mematuhi penyelenggaraan PSBB dan/atau mengahalang-halangi penyelenggaraan PSBB sehingga menyebabkan kedaruratan kesehatan masyarakat. Oleh karena Instruksi Gubernur Bali tersebut bukanlah instrumen hukum penyelengaraan PSBB sebagaimana diatur oleh UUKK jo PP PSBB jo Permenkes Pedoman PSBB tentu saja pelanggaran atas Instruksi Gubernur Bali tersebut in casu pelanggaran atas Diktum Ketiga mengenai pembatasan jumlah orang (maksimal 25 orang) dalam penyelenggaraan kegiatan adat dan agama di luar rumah tidak dapat dipidana dengan pasal 93 UU KK. Dengan demikian dalil penetapan tersangka; Made 
Suwardana selaku Ketua Panitia Pelaksana kegiatan ngaben massal Dadia Pasek Kubayan, di Desa Sudaji, Kecamatan Sawan Kabupaten Buleleng Provinsi Bali tidak tepat dan tidak sah hukum.

\section{Penutup}

Berdasarkan seluruh paparan di atas maka dapat disampaikan hal-hal sebagai berikut:

4.1 Kesimpulan

Penerapan Pasal 93 UU KK di wilayah yang tidak menetapkan penyelenggaran Kekarantinaan Kesehatan in casu PSBB tidak memiliki legalitas. Penyelenggaraan PSBB baik di tingkat Provinsi maupun Kabupaten harus dilakukan berdasarkan penetapan dari Menteri Kesehatan untuk penyelenggaraan PSBB. Secara normatif, Pasal 93 UUKK tidak dapat diterapkan terhadap kegiatan ngaben massal Dadia Pasek Kubayan, di Desa Sudaji, Kecamatan Sawan Kabupaten Buleleng Provinsi Bali karena memiliki kecacatan yuridis, sehingga penetapan Made Suwardana (Ketua Panitia Pelaksana) sebagai Tersangka tidak sah hukum.

\subsection{Saran}

Penyidik hendaknya tidak menggunakan Pasal 93 UUKK untuk mempidana Made Suwardana (Ketua Panitia Pelaksana) terlebih terdapat asas hukum pidana yakni asas ultimum remidium, sehingga hukum pidana adalah instrumen hukum terakhir.

\section{Daftar Pustaka}

\section{Buku}

Fockema, Andreae's, Juridisch Woordenboek, Tjeenk Willink. 1985.

Ridwan HR, Hukum Administrasi Negara, Raja Grafindo, Jakarta. 2006.

Hadjon, Philipus M., et al, Pengantar Hukum Administrasi Indonesia, Gadjahmada University Press, Yogyakarta. 2002.

Sudarto, Hukum Pidana I, Cet-2, Yayasan Sudarto Undip, Semarang. 1990.

\section{Jurnal}

Ajie, Radita. "Batasan pilihan kebijakan pembentuk undang-undang (Open legal policy) dalam pembentukan peraturan perundang-undangan berdasarkan tafsir Putusan Mahkamah Konstitusi", Jurnal Legislasi Indonesia, Nomor 2, Mei 2018.

Asyikin, Nehru, "Pengujian Freies Ermessen Atas Legislasi Semu Kepala Daerah", JURNAL HUKUM EKONOMI SYARIAH, Volume 3, Nomor 1, April 2020. 
Azhar, Muhamad, "Government Strategy in Implementing the Good Governance during COVID-19 Pandemic in Indonesia", Administrative Law \& Governance Journal, Nomor 2, Juni 2020.

Cohen, Jon and Kai Kupferschmidt, "Strategies shift as coronavirus pandemic looms", Science, Vol. 367, Issue 6481, February 2020.

Engkus, et al, "Covid-19: Kebijakan mitigasi penyebaran dan dampak sosial ekonomi di Indonesia", LP2M, Mei 2020.

Juaningsih, Imas Novita, "Penerapan Sanksi Pidana bagi Penimbun Masker di Indonesia Selama Masa Pandemi Covid-19", 'ADALAH, Nomor 1, 2020.

Ristyawati, Aprista, "Efektifitas Kebijakan Pembatasan Sosial Berskala Besar Dalam Masa Pandemi Corona Virus 2019 oleh Pemerintah Sesuai Amanat UUD NRI Tahun 1945", Administrative Law \& Governance Journal, Nomor 2, Juni 2020.

Telaumbanua, Dalinama, "Urgensi Pembentukan Aturan Terkait Pencegahan Covid-19 Di Indonesia", QALAMUNA: Jurnal Pendidikan, Sosial, dan Agama, Nomor 1, Pebruari 2020.

Susanto, Adelia Rachma Indriaswari et al, Tanpa Tahun Terbit, Kajian Politik Hukum Pemerintah dalam Penanganan Pandemi Covid-19, Tanpa Penerbit, Sleman.

Yunus, Nur Rohim, "Kebijakan Covid-19, Bebaskan Narapidana dan Pidanakan Pelanggar PSBB", 'ADALAH, Nomor 1, 2020.

\section{Internet}

https:/ /health.grid.id/read/352059111/who-resmi-nyatakan-covid-19-sebagaipandemi-global-setelah-menyebar-ke-118-negara?page=all

https:// www.vivanews.com/berita/dunia/40129-virus-corona-resmi-jadi-pandemiapa-artinya

https://news.detik.com/berita/d-4959761/pandemi-corona-jokowi-tetapkan-statusdarurat-kesehatan-masyarakat

https://nasional.kompas.com/read/2020/03/31/15265391/jokowi-tetapkan-statusdarurat-kesehatan-masyarakat

https://nasional.okezone.com/read/2020/04/01/337/2192229/isi-lengkap-keppreskedaruratan-kesehatan-masyarakat-covid-19-ditetapkan-presiden-jokowi

https://www.cnbcindonesia.com/news/20200401130638-4-149058/terbitkan-pp-psbbjokowi-ungkap-alasan-tak-lakukan-lockdown

https://nasional.kontan.co.id/news/hadapi-corona-pemerintah-terbitkan-pppembatasan-sosial-berskala-besar

https://www.antaranews.com/berita/1403506/permenkes-nomor-9-tahun-2020-aturpelaksanaan-psbb

https://mediaindonesia.com/read/detail/304863-permenkes-nomor-92020-harus-jadipedoman-penerapan-psbb

https://nasional.kompas.com/read/2020/04/22/19520061/bnpb-sudah-2-provinsidan-21-kabupaten-kota-yang-terapkan-psbb

https://mediaindonesia.com/read/detail/308807-bali-bersikukuh-tolak-ajukan-psbb

https://www.nusabali.com/berita/72379/gubernur-koster-belum-memperhitungkanpenerapan-psbb-di-bali

https:// bali.tribunnews.com/2020/05/10/3-indikator-bali-lebih-efektif-kendalikanpenyebaran-covid-19-dibanding-daerah-lain-terapkan-psbb

https://news.detik.com/berita/d-5012616/ini-strategi-bali-berhasil-lawan-coronatanpa-psbb 
https:// www.liputan6.com/regional/read/4247452/tanpa-psbb-bali-klaim-suksesatasi-corona

https://www.tribunnews.com/corona/2020/05/10/ini-strategi-yang-dipakaigubernur-bali-hingga-sukses-kendalikan-penyebaran-covid-19-tanpa-psbb

https://radarbali.jawapos.com/read/2020/05/04/192390/ketua-panitia-ngabenmassal-di-desa-sudaji-dijadikan-tersangka

https://regional.kompas.com/read/2020/05/04/16184561/warga-berkerumun-saatupacara-ngaben-ketua-panitia-jadi-tersangka?page $=$ all

https://nasional.kompas.com/read/2020/04/22/19520061/bnpb-sudah-2-provinsidan-21-kabupaten-kota-yang-terapkan-psbb

https://www.vivanews.com/berita/nasional/40702-pemprov-bali-tetapkan-statussiaga-penanggulangan-corona-covid-19?medium=autonext

https://jarrakpos.com/16/03/2020/perangi-covid-19-gubernur-koster-tetapkanstatus-bali-siaga-penanggulangan-covid-19/

https://bali.tribunnews.com/2020/03/16/breaking-news-pemprov-bali-tetapkanstatus-siaga-dalam-penanggulangan-covid-19

https://kumparan.com/kumparannews/gubernur-bali-tetapkan-status-siaga-coronakegiatan-agama-di-rumah-saja-1t2N2XasVSb/full

https:// www.vivanews.com/berita/nasional/43105-wabah-corona-nbsp-menggilabali-tetapkan-status-tanggap-darurat?medium=autonext

https://www.merdeka.com/peristiwa/pemprov-bali-tetapkan-status-tanggapdarurat-covid-19.html

https://mediaindonesia.com/read/detail/308807-bali-bersikukuh-tolak-ajukan-psbb

https://www.nusabali.com/berita/72379/gubernur-koster-belum-memperhitungkanpenerapan-psbb-di-bali

https://radarbali.jawapos.com/read/2020/04/29/191561/soal-psbb-di-bali-dewaindra-secara-substansi-sudah-lakukan

https://kumparan.com/kumparannews/pemprov-bali-soal-pp-psbb-sudahditerapkan-bahkan-lebih-luas-1t8j0DbOoXd

https://bali.tribunnews.com/2020/05/10/3-indikator-bali-lebih-efektif-kendalikanpenyebaran-covid-19-dibanding-daerah-lain-terapkan-psbb

https://news.detik.com/berita/d-5012616/ini-strategi-bali-berhasil-lawan-coronatanpa-psbb

https:// www.liputan6.com/regional/read/4247452/tanpa-psbb-bali-klaim-suksesatasi-corona

https://www.tribunnews.com/corona/2020/05/10/ini-strategi-yang-dipakaigubernur-bali-hingga-sukses-kendalikan-penyebaran-covid-19-tanpa-psbb

https://www.cnnindonesia.com/nasional/20200326172515-20-487231/dasarmaklumat-kapolri-keselamatan-rakyat-hukum-tertinggi

https://nasional.kontan.co.id/news/ini-isi-maklumat-kapolri-dalam-penangananpenyebaran-virus-corona

https://tirto.id/cegah-corona-polisi-akan-tindak-tegas-warga-tetap-buat-keramaian$\underline{\mathrm{eG} 7 \mathrm{o}}$

https://kbbi.web.id/maklumat

https://www.tagar.id/maklumat-kapolri-soal-pembubaran-perkumpulan-disoroti

\section{Peraturan perundang-undangan}

Undang-Undang Nomor 4 Tahun 1984 tentang Wabah Penyakit Menular

Undang-Undang Nomor 6 Tahun 2018 tentang Kekarantinaan kesehatan 
Peraturan Pemerintah Nomor 21 Tahun 2020 tentang Pembatasan Sosial Berskala Besar dalam rangka Percepatan Penanganan Corona Virus Disease 2019 (Covid 19)

Keputusan Presiden Nomor 11 Tahun 2020 tentang Penetapan Kedaruratan Kesehatan Masyarakat Covid 19

Peraturan Menteri Kesehatan Nomor 9 Tahun 2020 tentang Pedoman Pembatasan Sosial Berskala Besar Dalam rangka Percepatan Penanganan Corona Virus Disease 2019 (Covid 19)

Maklumat Kapolri Nomor: Maks/2/III/2020 tentang Kepatuhan Terhadap Kebijakan Pemerintah Dalam Penanganan Penyebaran Virus Corona (Covid 19)

Keputusan Gubernur Bali Nomor 258/04-G/HK/2020 tentang Penetapan Status Siaga Darurat Bencana Akibat Wabah Penyakit Corona Di Provinsi Bali

Keputusan Gubernur Bali Nomor 272/04-G/HK/2020 tentang Perpanjangan Status Siaga Darurat Bencana Akibat Wabah Penyakit Virus Corona di Provinsi Bali

Surat Keputusan Gubernur Bali Nomor 270/04-G/HK/2020 tentang Penetapan Status Darurat Tanggap Bencana Wabah Penyakit Akibat Virus Corona-19 di Propinsi Bali

Keputusan Gubernur Bali nomor 303/04-G/HK/2020 tentang Penetapan Perpanjangan Status Darurat Tanggap Bencana Wabah Penyakit Akibat Virus Corona-19 di Propinsi Bali

Instruksi Gubernur Nomor 8551 Tahun 2020 tentang Penguatan, Pencegahan dan Penanganan Covid 19 di Bali 